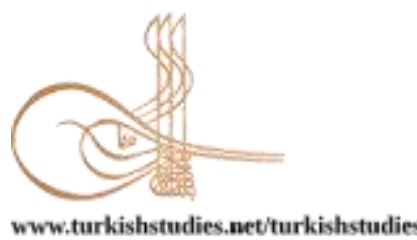

Turkish Studies

\title{
Sivil Havacılık İşletmesinde Toplam Kalite Yönetiminin ve Örgüt İ́liminin İş Tatmini Üzerindeki Etkisi*
}

\author{
In the Effect of Total Quality Management and Organizational Climate on Job Satisfaction in Clvil \\ Aviation Enterprise
}

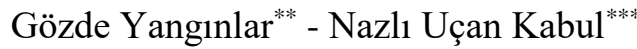

\begin{abstract}
The importance of the civil aviation sector has increased with the acceleration of international trade and logistics activities, Today, total quality management and organizational climate in civil aviation enterprises undertakes a strategic mission and play a key role in achieving competitive advantage. In this study, it is aimed to investigate the effect of total quality management and organizational climate on job satisfaction in enterprise operating in the field of civil aviation. The universe of the research is composed of employees working in a company operating in the field of civil aviation. For this purpose, a survey was conducted on 186 employees in the enterprise operating in the field of civil aviation. In the literature review, a study dealing with variables of total quality management, organizational climate and job satisfaction in the civil aviation sector could not be found. While evaluating the study data, descriptive statistical methods, factor analysis, correlation analysis, regression analysis were performed. Data analysis SPSS 24.0 package program was used. It is determined that there is a strong relationship between sub-factors of total quality management and organizational climate (customer orientation, full participation, leadership, continuous development, teamwork, continuous education, working environment, sense of trust, satisfaction) and job satisfaction in the civil aviation enterprise. As a result of the study, it was proved that "leadership and continuous education", which is one of the sub-factors of total quality management, and "trust and satisfaction," which are the sub-factors of organizational climate, have a positive effect on job satisfaction. This study is expected to make an important contribution to the businesses and literature in the field of civil aviation.
\end{abstract}

Structured Abstract: Global economic, commercial and political developments are effective in gaining dynamism of the civil aviation industry. In today's world, where competition increases, technology improves and the importance of providing customer satisfaction increases, the service quality and job satisfaction of the employees in the civil aviation sector should be high. The total quality management approach in the civil aviation industry plays a key role in gaining sustainable competitive advantage in the international arena. Total

\footnotetext{
${ }^{*}$ Bu makale yüksek lisans tezinden oluşturulmuştur.

** Dr.Öğr.Üyesi, İstanbul Ticaret Üniversitesi, İşletme Fakültesi, Uluslararası Lojistik ve Taşımacılık

Asst.Prof.Dr., Istanbul Commerce University, Faculty of Business Managment, International Logistics and Transportation ORCID 0000-0002-3814-2982

gyanginlar@ticaret.edu.tr

Yüksek Lisans Öğrencisi, Beykent Üniversitesi, Sosyal Bilimler Enstitüsü

Master Student, Beykent University, Institute of Graduate Studies

ORCID 0000-0003-0288-1676

nkabul@ hotmail.com

Cite as/ Atıf: Yangınlar, G., Uçan Kabul, N. (2020). Sivil havacılık ișletmesinde toplam kalite yönetiminin ve örgüt ikliminin iş tatmini üzerindeki etkisi. Turkish Studies, 15(3), 2073-2092.
}

https://dx.doi.org/10.29228/TurkishStudies.42946

Received/Geliş: 17 Nisan/April 2020

Accepted/Kabul: 20 June/Haziran 2020

Copyright $($ ) MDE, Turkey
Checked by plagiarism software

Published/Yayın: 25 June/Haziran 2020

CC BY-NC 4.0 
Quality Management practices increase the motivation of the employees and decrease the rates of absenteeism and turnover (İnce 2008:58). The quality groups formed within the organization strengthen both interdepartmental and intra-departmental relationships.

Employees who take an active role in the studies within the framework of total quality management will feel themselves as a part of the organization and will be effective in gaining functions. The employee who takes responsibility in the process will make more efforts to show a high performance; this will enable quality to increase and productivity to increase. Besides the satisfaction of the airline personnel with the job itself and their colleagues, promotion opportunities and reward system, it is also important in terms of job satisfaction that the salary is satisfactory. Job satisfaction is an emotional and mental well-being, a reaction that it gives to the climate of the organization, as well as having a motivating feature in the work of the organization (Tavas and Tekiner 2016: 196). Organizational climate is closely related to the mood of the employee. This is a phenomenon that affects the employees in the civil aviation industry with their passengers and colleagues, and their sense of belonging to the organization, and brings identity to the organization.

The aim of the study is to examine the effect of total quality management and organizational climate on job satisfaction in enterprises operating in the field of civil aviation. The sample of the study consists of 186 cabin crew in an enterprise operating in the field of civil aviation. Within the scope of the sample, "easy sampling method" was used, where data and information can be collected most easily As a result of the validity and reliability analysis, it was revealed that the compliance values of the measurement models for total quality management, organizational climate and job satisfaction were good and the structural validity of the model was ensured. Correlation analysis was conducted to determine the degree and direction of the relationship between the variables. In the study, it was determined that total quality management and organizational climate had a positive effect on job satisfaction

Keywords: Civil Aviation, Total Quality Management, Organizational Climate, Job Satisfaction.

Öz: Uluslararası ticaret ve lojistik faaliyetlerin ivme kazanmasıyla, sivil havacılık sektörünün önemi daha da artmıştır. Günümüzde sivil havacılık işletmelerindeki toplam kalite yönetimi ve örgüt iklimi stratejik bir misyon üstlenmekte ve rekabet avantajının elde edilmesinde kilit bir rol oynamaktadır. Bu çalışmada, sivil havacılık alanında faaliyet gösteren bir işletmede toplam kalite yönetiminin ve örgüt ikliminin iş tatmini üzerindeki etkisinin incelenmesi amaçlanmaktadır. Araştırmanın evrenini, sivil havacılık alanında faaliyet gösteren bir işletmede görev alan çalışanlar oluşturmaktadır Bu amaç kapsamında, sivil havacılık alanında faaliyet gösteren işletmedeki 186 çalışana yönelik anket çalışması yapılmıştır. Literatür taramasında, sivil havacılık işletmesinde toplam kalite yönetimi, örgüt iklimi ve iş tatmini değişkenlerini ele alan bir çalışmaya rastlanılamamıştır. Çalışma verileri değerlendirilirken tanımlayıcı istatistiksel metotlar, faktör analizi, kolerasyon analizi, regreyon analizi yapılmıştır. Verilerin çözümlemesi SPSS 24.0 paket programı kullanılmıştır. Sivil havacılık işletmesinde toplam kalite yönetimi ve örgüt iklimi alt faktörleri (müşteri odaklılık, tam katılım, liderlik, sürekli gelişme, takım çalışma, sürekli eğitim, çalışma ortamı, güven duygusu, doyum) ile iş tatmini arasında güçlü bir ilişki olduğu belirlenmiştir. Çalışmanın sonucunda, toplam kalite yönetimi alt faktörlerinden "liderlik ve sürekli eğitimin" ve örgüt İklimi alt faktörlerinden 'güven duygusu ve doyumun', iş tatmini üzerinde pozitif bir etkisi olduğu kanıtlanmıştır. Bu çalışmanın sivil havacılık alanında faaliyet gösteren işletmelere ve literatüre önemli bir katkı sağlayacağı öngörülmektedir.

Anahtar Kelimeler: Sivil havacılık, Toplam kalite yönetimi, Örgüt iklimi, İş tatmini.

\section{Giriş}

Küresel ekonomik, ticari ve siyasi gelişmeler, sivil havacılık sektörünün dinamizm kazanmasında etkili olmaktadır. Rekabetin arttığ1, teknolojinin geliştiği ve müşteri memnuniyeti sağlamanın öneminin daha da arttığı günümüzde, sivil havacılık sektöründe hizmet kalitesinin ve çalışanların iş tatmininin yüksek olması gerekmektedir. Sivil havacılık sektöründe toplam kalite yönetimi yaklaşımı, uluslarararası alanda sürdürülebilir rekabet avantajı elde edilmesinde anahtar bir rol üstlenmektedir. Toplam Kalite Yönetimi uygulamaları, işgörenlerin motivasyonunu artırarak, devamsızlık ve işten ayrılma oranlarını azaltmaktadır (İnce 2008:58). Örgüt içerisinde 
oluşturulan kalite grupları hem departmanlar arası hem de departman içi ilişkileri güçlendirmektedir. Toplam kalite yönetimi çerçevesinde çalışmalarda aktif rol alan çalışan, kendini örgütün bir parçası olarak hissedecek ve kararların işlev kazanmasında etkin olacaktır. Süreçte sorumluluk alan işgören yüksek bir performans göstermek amacıyla daha fazla çaba gösterecektir; bu durum kalitenin artmasına ve verimliliğin yükselmesine imkan sağlayacaktır.

Havayolu işletmesi personelinin işin kendisinden ve çalışma arkadaşlarından, terfi olanaklarından ve ödül sisteminden memnun olmasının yanı sıra ücretin tatmin edici düzeyde olması da iş tatmini açısından önem arz etmektedir. İş tatmini, çalışanın duygusal ve zihinsel açıdan kendini iyi hissetmesi, örgütün amaçları doğrultusunda çalışmasında motive edici bir özelliğe sahip olmasının yanı sıra örgüt iklimine karşı verdiği bir reaksiyondur (Tavas ve Tekiner 2016:196). Örgüt iklimi çalışanın ruh hali ile yakından ilişkilidir. Bu durum, sivil havacılık sektöründeki çalışanların yolcularla ve iş arkadaşlarıyla olan ilişkilerini, örgüte duydukları aidiyet duygularını etkileyen ve örgüte kimlik kazandıran bir olgudur.

Çalışmanın amacı, sivil havacılık alanında faaliyet gösteren işletmelerde toplam kalite yönetiminin ve örgüt ikliminin iş tatmini üzerindeki etkisini irdelemektir. Araştırmanın örneklemini sivil havacılık alanında faaliyet gösteren bir işletmedeki 186 kabin memuru oluşturmaktadır. Örnek kapsamında verilerin ve bilgilerin en kolay toplanabileceği "kolayda örnekleme yöntemi", kullanılmıştır. Çalışmamız beş bölümden oluşmaktadır. Birinci bölümde giriş, ikinci bölümde ise literatür taramasına yer verilmiştir. Üçüncü bölümde araştırmanın amacı, önemi, yöntemi ve modeli ele alınırken, dördüncü bölümde verilerin analizi ve sonuçları yer almaktadır. Beşinci bölümde, sonuç ve değerlendirmeler ele alınmıştır.

\section{Literatür Araştırması}

\section{Sivil Havacilık}

Askeri amaçlı ya da güvenlik sağlama, gümrük ve sınır kontrolü gibi görevler dışında kalan tüm havacılıkla ilgili faaliyetler, sivil havacılık olarak tanımlanmaktadır. Ticari yolcu ve yük taşımacılığı ya da spor etkinlikleri çerçevesinde planör, yamaç paraşütü gibi faaliyetler, sivil havacılığın kapsamı içerisinde yer almaktadır (Çalıyurt 2012:7). Sivil havacılık sektörü; ticari, ekonomik, siyasi ve kültürel açıdan önemli bir karakteristik özelliğe sahip, yoğun rekabetin olduğu ve ileri teknolojinin kullanıldığı sektörlerin başında gelmektedir (Hine 2000:176).

Dünya genelinde sivil havacılığın serbestleşme hareketinin etkisiyle uçuş programlarındaki ve bilet fiyatlarındaki kısıtlamaların kaldırılması, özel yatırımcıların sivil havacılık alanında faaliyet göstermesinin önünü açmıştır. Bu gelişmeler, Türk sivil havacılık sektörünün rekabetçi bir yapıya kavuşmasına ve havayolu taşımacılık hizmet kalitesi öneminin daha da artmasına imkan sağlamıştır (Bakır ve diğ. 2017:155). Sivil havacılık sektöründeki bu değişim, ülkelerin küreselleşmeye olan entegrasyonlarının hızlanmasına kaynaklık etmektedir (Yüksek 2014:1).

Akın ve Günay (2015) çalışmasında, havayolu yer hizmetleri faaliyetlerinin kalitesini ölçmek amacıyla Servqual yöntemini kullanmışlardır. ISO 10002 müşteri memnuniyeti kalite yönetimi sisteminin etkinliğinin sağlanmasında, toplam kalite anlayışının bütün çalışanlar tarafından benimsenmesinin önemini vurgulamışlardır. Türk (2018) havayolu işletmesi çalışanlarının demografik özelliklerinin performansları üzerinde pozitif yönlü bir etkisi olduğunu kanıtlamıştır. Kiracı ve Bayrak (2014) çalı̧̧malarında ise, havacılık sektöründeki iş yoğunluğunun ve iş stresinin yüksek olması iş tatmini etkilediğini vurgulamaktadırlar. Yılmaz (2017) çalışmasında havayolu yolcu hizmetleri departmanında görev alan personele yönelik olarak örgüt iklimi alt değişkenlerinden çalışma koşullarını değerlendirmiş̧tir. Çalışmanın sonucunda çalışma koşullarından kaynaklanan memnuniyet düzeylerinin negatif eğilimli olduğu saptanmıştır. Talebi ve Yıldırım (2017) havayolu yer hizmetleri işletmesinin müşteri memnuniyetini sağlamasında, 
toplam kalite ilkelerini benimsemesi ve bu ilkeleri bütün iş süreçlerine entegre etmesinin etkili olduğuna değinmektedir.

\section{Toplam Kalite Yönetimi}

Toplam kalite yönetimi, uzun vadeli hedeflerle müşteri tatminini sağlamayı amaçlayan, maddi ve manevi işletme kaynaklarını bir bütünlük içerisinde değerlendiren bir anlayış olarak tanımlanmaktadır. Bu kavram ürün ve hizmet üretiminde kaliteyi temel esas alan, örgütün bütün üyelerinin katılımını sağlamayı amaçlayan ve ekip çalışmasının ön planda yer aldığı insan odaklı bir yönetim anlayışı olmasının yanısıra, müșterinin istek ve beklentilerine ve çalışanlara değer veren felsefi bir yaklaşımdır (Cua ve diğ. 2001:676; Tari, 2005:183).

Toplam kalite yönetimi dikey iletişimin ve bürokrasinin hakim olduğu, tek liderlik anlayışının aksine; yatay iletişimi benimseyen, çalışanların tam katılımını sağlayan, sürekli iyileşmenin ve gelişmenin ilke edinildiği bir olgudur (Ugboro ve Obeng, 2000:249). Toplam kalite yönetimi yaklaşımında, ürün ve hizmetlerin hatasız bir şekilde üretilmesi, maliyetlerin minimize edilmesi ve müşteri memnuniyetinin sağlanması amaçlanmaktadır (Mehra ve Ranganathan 2008:914; Fuentes ve diğ. 2004:429). Toplam kalite yönetimi yaklaşımı müşteri odaklılık, tam katılım, liderlik, sürekli gelişme, takım çalışması ve sürekli eğitim gibi birçok unsuru kendi içerisinde barındırmaktadır.

-Müşteri Odaklılık: İşletmelerin varlıklarını sürdürmede en önemli unsurlardan biri de müşterilerin istek ve beklentilerini karşılayacak şekilde ürün ve hizmetler üreterek müşteri memnuniyeti sağlamaktır.

-Tam Katılım: 21.yüzyılda işgörenler problemlerin saptanmasında ve çözümünde aktif olarak yer almayı talep etmektedir. Bir işi en iyi bilen, o işi en iyi yapandır. Tam katılımın sağlanmasında çalışanların sorumluluklarının, yetkilerinin belirlenmesi ve kalite çemberleri oluşturarak çalışanların sürece dahil edilmesi temel esastır (Akdağ 2005:165).

-Liderlik: Üst yönetimin liderliği örgütsel değişimi ve gelişimi doğrudan etkilemektedir (Reed ve diğg. 2000:13). Liderin görevi, çalışanların hatalarını tespit etmek ve bu hataların oluşmasını engelleyecek adımları atarak, kaliteyi daha üst seviyelere çıartmaktır. Erturgut (2009) çalışmasında, örgüt içerisinde dönüşümcü liderin etkinliği arttıkça, toplam kalite yönetiminin başarısının da arttığını belirtmektedir.

-Sürekli Gelişme: İşletmelerin yenilikçi gelişmeyi sürdürmesinde ve hedeflerine ulaşmasında etkili olan bir felsefedir (Das ve diğ. 2008:55).Sürekli gelişme örgütün her kademesinde aktif bir şekilde üst yönetim tarafından teşvik edilmelidir (Al-khalifa ve Aspinwall 2000:194). Ustasüleyman (2011) çalışmasında, toplam kalite yönetimi alt faktörlerinde sürekli iyileşme ve liderliğin işletme performansını pozitif yönde etkilediği sonucuna ulaşı1ırken; eğitimin ve müşteri odaklılığın işletme performansı üzerinde anlamlı bir etkiye sahip olmadığı tespit edilmiştir.

-Takım Çalışması: Örgüt içerisindeki sorunların çözümü ve süreçlerin etkinleştirilmesi, takım çalışmalarının niteliği ve niceliğine bağlıdır. Toplam kalite yönetimi yaklaşımında o işi en iyi bilen kişi, işi yapan kişi olarak değerlendirilmektedir. İş yapan kişi ile süreçlerdeki çalışanların yer aldığı kalite çemberlerinin oluşturulması kalitenin ivme kazanmasında etkili olmaktadır (Aykaç ve Özer 2006: 178).

-Sürekli Eğitim: İşletmelerin işgörenlere sürekli bir şekilde eğitim vermesi, değişen çevre koşullarına uyum sağlamayı kolaylaştırmakta ve örgütün daha esnek bir yapıya sahip olmasına olanak sağlamaktadır. Özçakar (2010) kamu kuruluşlarında toplam kalite yönetiminin işlev kazanmasında eğitimin önemine vurgu yapmaktadır. Eğitim seviyesi yüksek olan çalışanların, yetersizliklerin daha çok farkında olduğuna değinmektedir. 


\section{Örgüt İklimi}

Örgüt iklimi, çalışanların tutumları ve davranışları sonucu oluşan, çalışma ortamındaki işgörenler tarafından doğrudan ya da dolaylı olarak algılanan, ortak bir algının yaratılmasında rol oynayan bir kavramdır (Gök 2009:589). Normlar, inançlar, prosedür, örgütsel değerler hakkında örgüt içerisinde oluşan ortak bir algı, örgüt iklimini meydana getirmektedir (Silva ve diğ. 2004). Örgüt iklimi işgörenlerin davranışlarını ve motivasyonunu etkilediği varsayılan, ölçülebilir özellikler kümesi olarak tanımlanmaktadır (Litwin ve Stringer 1974). Bu kavram, örgütün özellikleri ve bu özelliklerin işgören davranışları üzerinde nasıl bir etkiye sahip olduğunu açıklamaktadır (Halis ve Uğurlu 2008:102). Örgütün fiziksel yapısı tüm işgörenler tarafından aynı değerlendirilirken, örgüt ikliminin psikolojik boyutu işgörenden işgörene değişebilmektedir (Tutar ve Altınöz 2010:197). Ödüllendirme, nezaket, içtenlik gibi örgüt ikliminin psikolojik boyutları, çalışma yaşamındaki tutum ve davranışları biçimlendirmektedir (Türen ve diğ. 2014:173).

Örgüt iklimi, literatürde çalışma ortamı, güven duygusu ve doyum başlıkları altında incelenmektedir (Ölçer 2005; Öktem ve diğ. 2016; Örücü ve diğ. 2006).

•Çalışma Ortamı: Örgüt iklimi, işgörenlerin davranışlarını etkileyen ve örgütün diğer örgütlerden ayırt edilmesine olanak sağlayan iç özellikler bütünüdür (Şentürk ve Sağnak 2012:31). Örgütteki iletişim, liderin tutumu, saygı ve güven ortamı, örgüt içerisindeki ekip çalışmasını ve karar vermeye katılımı etkileyerek, çalışanların örgütsel faaliyet ve projelere katılımına imkan sağlamaktadır. Liderin tutum ve davranışları örgütün performansını olumlu ya da olumsuz yönde etkileyebilmektedir. Korkmaz (2011) çalışmasında, dönüşümcü liderin işgörenlerin kendilerini geliştirmelerine imkan sağlamasının, onlara rehberlik etmesinin işletme verimliliğini ve etkinliğini arttırdığına değinmektedir. Çalışma arkadaşları ve yöneticileri tarafindan saygı gördüğünü hisseden işgörenin mesleki bağlılığı artmakta ve işten ayrılma niyeti de azalmaktadır (Demircan ve Ceylan, 2003:140; Uysal, 2013:94).

•Güven Duygusu: Örgütte güvene dayalı ilişkilerin hakim olması, işgörenlerin örgüte güven duymalarına ve kendilerini örgütün bir parçası olarak tanımlamalarına kaynaklık eder. Çalışanın ihtiyaç duyduğunda yardım alabileceğine dair güven duyması, iş ile ilgili bir sorun olduğunda rahatça konuşabileceğine inanması, güven duygusunu geliştirmektedir (İşcan ve Karabey, 2007:188). Güven ilkesi çerçevesinde eleştiriye açık, net bir iletişim ortamının bulunması yaratıcılığın ve yenilikçiliğin önünü açmaktadır (Güzeler ve Dedeoğlu, 2016:129).

-Doyum: Doyum dinamik bir yapıya sahip olup, sürekli gözetim ve denetim altında tutulmas1 gereken bir süreçtir. Örgütsel yapıda var olan ya da gelecekte olması muhtemel sorunların belirlenmesi ve örgüt içi iletişimin artırılması doyumun sağlanmasında etkili olmaktadır(Öztürk ve Özdemir 2003:192).

Uysal ve Aydemir (2014) çalışmasında, örgüt ikliminin faktörlerinden karşılıklı güven duygusu, işin önemi, mesleki ve örgütsel ruh, işbirliği ve çatışmanın çalışma psikolojisi üzerinde anlamlı bir etkiye sahip olduğuna dikkat çekmektedir. Schneider (1983) çalışmasında ise, örgüt ikliminin yenilikçi davranışları etkilediği sonucuna ulaşmıştır. Eroğluer ve Yılmaz (2015) çalışmalarında örgüt iklimini 4 alt boyutta " iletişim, yenilik, açıklılık, ödüllendirme" olmak üzere ele almıştır. Tekstil sektöründeki işin niteliğinin ve çalışma koşullarının (işlerin basit, monoton olması, çalışma şartlarının ağır olması, işgörenlerin büyük çoğunluğunun genç ve vasıfsız olması) iş tatminsizliğine neden olabileceğine vurgu yapmaktadır. Akbulut ve Kutlu (2016) çalışmalarında sağlık sektöründe örgüt ikliminin yaş, eğitim ve medeni durum açısından, Sezgin ve Kılınç (2011) ise eğitim sektöründe örgüt ikliminin cinsiyet, eğitim branşı ve çalışma süresi açısından anlamlı bir farklılık yaratmadığ 1 sonucuna ulaşmışlardır. 
Kasırga ve Özbek'in (2008) çalışmalarında, eğitim sektöründe başarı ve yaratıcılığa dayalı özendirici iklimin hakim olduğu, akademisyenlerin işlerine bağlı ve çalışma ortamından memnun oldukları tespit edilmiştir. Öktem ve diğg. (2016) çalışmalarında turizm sektöründe örgüt iklimin iş tatmini üzerinde pozitif yönlü bir etkiye sahip olmadığını kanıtlamıştır. Satın alma karar süreci, tüketicinin bir ihtiyacının ortaya çıkmasıyla başlayan, ihtiyacı gidermek için yaptığı araştırmalarla devam eden, mevcut alternatiflerin değerlendirilerek alternatiflerden birinin seçiminin yapılması, satın alma kararının verilmesi ve satın alınan ürünün tüketilmesinden sonraki davranışlar ile son bulan bir süreci ifade etmektedir.

\section{İş Tatmini}

Günümüzde işletmelerin varlıklarını sürdürmelerinde, hedeflerine ulaşmada ve gelişmelere adapte olmalarında insan kaynağı en önemli unsurların başında gelmektedir (Kumar ve diğ. 2013:1; Chaulagain ve Khadka 2012:32). İş tatmini, çalışanın işinden beklediği ile elde ettiğini değerlendirmesi sonucunda pozitif bir duygunun oluşması olarak tanımlanmaktadır (Federici ve Skaalvik 2012:300; Şeker ve Zırhlıoğlu 2009:6). İşgörene haz veren duygusal bir olgu ve aynı zamanda karşılanmış işgören beklentilerinin kümülatif değeridir (Schwepker 2001:41; Hwang ve Kuo, 2006:255).

İş tatmini, çalışanın işinin özellikleri ile kendisinin özelliklerinin uyumlu olduğunun ve işi ile ne kadar mutlu olduğunun bir göstergesidir (Mrayyan 2005). İş tatmini çevresel, psikolojik ve fiziksel faktörlerden etkilenmesinin yanısıra örgütsel bağl1lı̆̆1, performansı, motivasyonu da etkileyen bir unsurdur (Akkoç ve diğ. 2012). İşletmelerin verimliliğinin ve etkinliğinin artmasında, rekabet avantaji elde etmesinde iş tatmini anahtar bir rol üstlenmektedir (Dedeoğlu ve diğ. 2016:51). İşinden memnun olmayan işgörenler, yeni iş olanaklarını değerlendirerek işten ayrılmaya karar verebilmektedirler; bu nedenle iş tatmini, çalışanın işine ilişkin duygusal, bilişsel ve değerlendirici tepkilerini yansıtan bir tutumdur (Sökmen ve Aydınlatan 2016). İş tatminsizliği durumunda, personelin işten ayrılma niyeti ve devamsızlık artmakta (Boymul ve Özeltürkay 2017:94), örgütsel bağl11ık ve işletme performansı düşmektedir (Varol ve diğ. 2017:286).

Arslan ve Demir (2017) çalışmalarında, çalışanları motive eden faktörlerin iş tatmini düzeyi üzerinde olumlu etkiye sahip olduğu ve hizmet kalitesini arttırdığını savunmaktadır. Tepe Küçükoğlu (2018) çalışmasında, işgören açısından işin öneminin ve özerklik durumunun iş tatminini doğrudan etkilediğini ileri sürmektedir. Oğuzhan ve diğ. (2017) ise, örgüt ikliminden kaynaklanan psikolojik sermaye ve duygusal emeğin iş tatminini etkilemediği sonucuna ulaşmışlardır. Şimşek ve Kara (2017) çalışmalarında örgüt ikliminin iş tatminini etkilediğine vurgu yapmıştır. İşgörenlerin yüksek başarı güdüsüne sahip olmalarında ve verimli bir şekilde faaliyet göstermelerinde örgüt ikliminin yönetilmesi kritik bir öneme sahiptir (Shalley ve diğ. 2000).

Örgüt iklimi organizasyonda yeniliğin gelişmesine ve işletmelerin rekabet avantajı elde etmesine kaynaklık etmektedir (Özbağ 2012:156). İş tatmini düzeyi demografik değişkenlere göre birçok çalışmada incelenmiştir. İş tatmininin cinsiyete göre değişmediğini ileri süren birçok çalışma (Azım ve diğ. 2013; Suki ve Suki, 2011) literatürde yer almaktadır. Clark (1997) çalışmasında, kadın çalışanların kötü çalışma şartlarında olmalarına rağmen beklentilerinin erkeklere göre daha düşük olmasından dolayı, iş tatmini düzeylerinin yüksek olduğunu savunmaktadır. Arslan ve Demir, (2017) çalışmalarında işgörenlerin eğitim düzeyleri arttıkça iş tatmin seviyelerinin de arttı̆̆ını; (Roche 2014) ise çalışmasında azaldığını saptamıştır. Evli işgörenlerin iş tatmin düzeylerinin bekarlardan daha yüksek olduğu görülmektedir (Arslan ve Demir, 2017; Orhan ve Komşu, 2016). 


\section{Yöntem}

\section{Araştırmanın Amacı ve Örneklem}

Bu çalışmada, sivil havacılık işletmesinde toplam kalite yönetiminin ve örgüt ikliminin iș tatmini üzerindeki etkisinin ölçülmesi amaçlanmaktadır. Bu bağlamda toplam kalite yönetimi 5 faktör altında "Müşteri Odaklılık, Tam Katılım, Liderlik, Sürekli Gelişme, Takım Çalışması, Sürekli Eğitim", örgüt iklimi 3 faktör "Çalışma ortamı, Güven Duygusu, Doyum” altında incelenmiştir. Araştırmada betimsel araştırma yöntemi kullanılmıştır. Alınan bilgiler ışığında ana kitleden, örnek kapsamına bilgi ve verilerin en kolay toplanabileceği 'kolayda örnekleme yöntemi' kullanılmıştır.

\section{Araştırmanın Verilerinin Toplanması ve Ölçeklerin Oluşturulması}

Araştırmanın evrenini, sivil havacılık alanında faaliyet gösteren bir işletmede görev alan çalışanlar oluşturmaktadır. İlk önce araştırmada uygulanan anketin geçerli ve araştırmanın amacına uygun olduğunu test etmek amacıyla, 30 personele pilot anket çalışması yapılmıştır. Ön çalışmadan elde edilen bilgiler ışığında anket formuna son şekli verilmiştir. Araştırmanın evrenini 360 sivil havacılık işletmesi kabin memuru için $\% 95$ güven düzeyi ve $\% 5$ tolerans düzeyinde örneklem büyüklüğünün 186 olması yeterli bulunmaktadır. Anket formu linki oluşturularak katılımcılara email yoluyla iletilmiş, anket çalışması hakkında bilgi verilerek ankete katılım sağlamaları talep edilmiştir.

Toplanan veriler drive.google.com üzerinden Excel yardımıyla SPSS (Statistical Package for Social Sciences) programına aktarılmıştır. Araştırmada sivil havacılık işletmesindeki çalışanlara, demografik özellikleri içeren sorular hariç, toplam 58 sorudan oluşan bir anket formu düzenlenmiştir. Demografik özellikleri belirlemeye yönelik sorular hariç tüm önermelerde 5'li Likert Tipi ölçeğinden yararlanılmıştır. Değerlendirmede (1) Kesinlikle katılmıyorum, (2) Katılmıyorum, (3) Kararsızım, (4) Katılıyorum, (5) Kesinlikle katılıyorum seçenekleri kullanılmışır. Anket sorularının oluşturulması sırasında basit ve anlaşılır bir dil kullanılmasına özen gösterilmiştir.

Anket formu iki temel bölümden oluşmaktadır. Birinci bölümde 7 soruyla çalışanların demografik özelliklerinin belirlenmesine çalışılmıştır. İkinci bölümde ise; toplam kalite yönetimi, örgüt iklimi ilkelerini ve iş tatminini içeren soru grupları yer almaktadır. Toplam kalite yönetimi uygulamaları değerlendirmeye yönelik 27 soru, Samson ve Terziovski, (1999), Anderson ve dĭg. (1995), Tari ve diğ. (2007), Fuentes ve diğ. (2007), Bou-Llusar ve diğ. (2009), Prajogo ve Sohal,

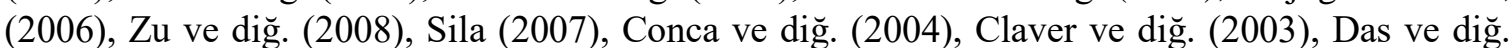
(2000) çalışmalarından derlenmiştir. Örgüt iklimini değerlendirmeye yönelik 13 soru, Ölçer (2005), Öktem ve diğ. (2016) ve Örücü ve diğ. (2006) çalışmalarından; iş tatminini değerlendirmeye yönelik 11 soru ise İnce (2008), Örücü ve diğ. (2006), Liao ve Chuang, (2004) ve Öktem ve diğg. (2016) çalışmalarından faydalanarak oluşturulmuştur.

\section{Araştırma Modeli ve Hipotezleri}

Araştırmanın amacı çerçevesinde bir model geliştirilmiş olup, Şekil 1'te yer almaktadır. 


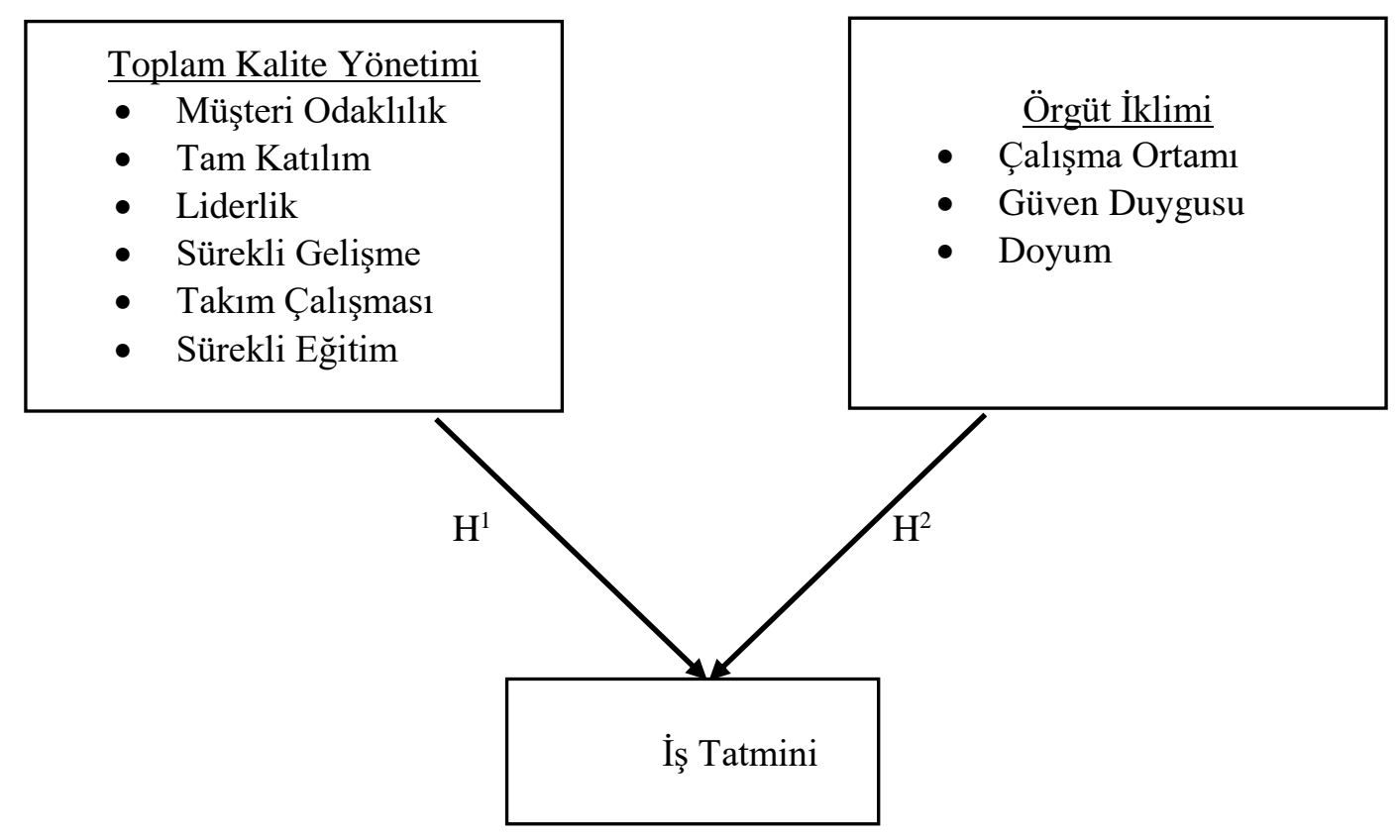

Şekil 1: Araştırmanın Modeli

\section{Araștırmanın Bulguları ve Değerlendirilmesi}

\section{Demografik Özellikleri Göre Bulgular}

Çalışmaya katılan kabin ekiplerinin cinsiyet, yaş, medeni hal, eğitim düzeyi, gelir düzeyi, unvanı ve işletmedeki çalışma süresine ait frekans dağılımları ve \% değerleri Tablo1'de sunulmaktadır.

Tablo 1: Sivil Havacılık Çalışanlarının Demografik Özelliklerinin Frekans Dağılımı

\begin{tabular}{|c|c|c|c|c|c|}
\hline \multicolumn{6}{|c|}{ Demografik Değişkenlere Ait Frekans Dağılımları } \\
\hline Cinsiyet & Frekans & $\%$ & Öğrenim Durumu & Frekans & $\%$ \\
\hline Kadın & 103 & 55,4 & Lise & 40 & 21,5 \\
\hline Erkek & 83 & 44,6 & Lisans & 114 & 61,3 \\
\hline Toplam & 186 & 100,0 & Yüksek Lisans & 30 & 16,1 \\
\hline Yaş & Frekans & $\%$ & Doktora & 2 & 1,1 \\
\hline 18-24 & 15 & 8,1 & Toplam & 186 & 100,0 \\
\hline 25-34 & 71 & 38,2 & Medeni Durum & Frekans & $\%$ \\
\hline $35-44$ & 81 & 43,5 & Evli & 110 & 59,1 \\
\hline 45 yaş ve üstü & 19 & 10,2 & Bekâr & 76 & 40,9 \\
\hline Toplam & 186 & 100,0 & Toplam & 186 & 100,0 \\
\hline Gelir Durumu & Frekans & $\%$ & Çalışma Süreleri & Frekans & $\%$ \\
\hline 2500 TL ve daha az & 5 & 2,7 & 1 y1ldan az & 3 & 1,6 \\
\hline 2501-3500 TL & 6 & 3,2 & $1-2$ y1l & 15 & 8,1 \\
\hline 3501-4500 TL & 18 & 9,7 & 3-5 y1l & 49 & 26,3 \\
\hline 4501-5500 TL & 26 & 14,0 & $6-10 \mathrm{y} 1 \mathrm{l}$ & 50 & 26,9 \\
\hline $5501-6500$ TL & 22 & 11,8 & $11-15 \mathrm{y} 1 \mathrm{l}$ & 22 & 11,8 \\
\hline 6501 TL ve üzeri & 109 & 58,6 & 15 yıldan fazla & 47 & 25,3 \\
\hline Toplam & 186 & 100,0 & Toplam & 186 & 100,0 \\
\hline
\end{tabular}


Örneklemde yer alan sivil havacılık çalışanlarının demografik özellikleri Tablo 1'de verilmiştir. Cinsiyet değişkenine göre katılımcıların \%55,4'ünün kadın ve \%44,6'sının erkek olduğu görülmektedir. Yaş değişkenine göre, katılımcıların en çok 35-44 yaş arasındaki işgörenlerden oluştuğu belirlenmiştir. Araştırmada yer alan çalışanların büyük bir çoğunluğunun üniversite mezunu olduğu ve işgörenlerin \%58,6'sının aylık gelirinin $6500 \mathrm{TL}$ ve üzeri olduğu tespit edilmiştir. Bekâr çalışan sayısının, evli çalışan sayısına yakın olduğu, çok fark olmadığı gözlenmiştir. İşgörenlerin işletmedeki görev sürelerinin ağırlıklı olarak 6-10 yıl olduğu ve 15 yıldan fazla görev alan tecrübeli işgören oranın çok yüksek seviyeler olduğu $(\% 25,3)$ görülmektedir.

\section{Değişkenlere Ait Güvenirlik ve Faktör Analizi}

Araştırmada kullanılan ölçeklerin geçerliliğini ve temel faktörlerin neler olduğunu belirlemek amacıyla çok sık tercih edilen Varimax tekniği ile faktör analizi uygulanmıştır. KMO ve Bartlett's test analizleri sonucunda; toplam kalite yönetimi ölçeğinin KMO değerinin (0.942), örgüt iklimi ölçeğinin KMO değerinin (0.917) ve iş tatmini ölçeğinin KMO değerinin (0.877) mükemmel düzeyde olduğu tespit edilmiştir. Üç ölçeğinde Bartlett's test sonuçları istatistiksel olarak anlamlı bulunmuştur. Güvenirlik analizi sonuçlarına bakıldığında; toplam kalite yönetimi $(\alpha=0.968)$, örgüt iklimi $(\alpha=0.944)$ ve iş tatmini $\alpha=0.918)$ ölçeklerinin yüksek derecede güvenilir ölçekler olduğu belirlenmiştir. Toplam kalite yönetimi alt faktörlerinden müşteri odaklılık ( $\alpha=0.923)$, örgüt iklimi alt faktörlerinden çalışma ortamı $(\alpha=0.903)$ en yüksek güvenirlik katsayısına sahiptir.

Çalı̧̧mamızda yer alan toplam kalite yönetimi, örgüt iklimi ve iş tatmini değiş̧kenlerine ait geçerlilik ve güvenirlik analizleri Tablo 2, Tablo 3 ve Tablo 4'de yer almaktadır.

Tablo 2: Toplam Kalite Yönetiminin Geçerlilik ve Güvenirlik Analizi

\begin{tabular}{|c|c|c|}
\hline & KMO & $\begin{array}{l}\text { Cronbach's } \\
\text { Alpha }\end{array}$ \\
\hline Müşteri Odaklılık & $\mathbf{0 , 8 7 0}$ & \\
\hline Sivil havacılık işletmesi, müşteri memnuniyetine önem verir. & 0,919 & \\
\hline Sivil Havacılık işletmesi, müşteri istek ve beklentilerini dikkate alır. & 0,926 & \\
\hline Sivil Havacılık işletmesi, müşterilerin neye ihtiyacı olduğu araştırır. & 0,899 & 0,923 \\
\hline Sivil Havacılık işletmesi, müşteri memnuniyeti ölçümünü düzenli olarak yapar. & 0,871 & \\
\hline Sivil Havacılık işletmesi, çalışanlarını iç müşteri olarak kabul eder. & 0,777 & \\
\hline Tam Katılım & 0,847 & \\
\hline $\begin{array}{l}\text { Sivil havacılık işletmesi çalışanları, sektörle ve şirketle ilgili yeterli bilgiye } \\
\text { sahiptir. }\end{array}$ & 0,776 & \\
\hline $\begin{array}{l}\text { Sivil havacılık işletmesi çalışanları görüşlerini söyleyebilir, önerilerde } \\
\text { bulunabilir ve işletmenin herhangi bir faaliyeti hakkında soru sorabilir. }\end{array}$ & 0,882 & 0,902 \\
\hline $\begin{array}{l}\text { Sivil havacılık işletmesi çalışanları, sosyal sorumluluk stratejilerine tam katılım } \\
\text { sağlar. }\end{array}$ & 0,883 & \\
\hline Sivil havacılık işletmesi çalışanlar, yeniliklerin ortaya çıkarılmasına katkı sağlar. & 0,867 & \\
\hline $\begin{array}{l}\text { Sivil havacılık işletmesi çalışanlarına teknolojik ve idari konularda inisiyatif } \\
\text { tanır. }\end{array}$ & 0,834 & \\
\hline Liderlik & 0,840 & \\
\hline $\begin{array}{l}\text { Sivil havacılık işletmesinin çalışanlara tebliğ edilen ve çalışanlar tarafindan } \\
\text { desteklenen bir misyon bildirimi vardır. }\end{array}$ & 0,785 & \\
\hline Sivil havacılık işletmesinde üst yönetim, performansa yönelik hedeflere sahiptir. & 0,846 & \\
\hline $\begin{array}{l}\text { Sivil havacılık işletmesinde çalışanların performansını izlemek için kullanılan } \\
\text { bir performans ölçüm sistemi mevcuttur. }\end{array}$ & 0,800 & 0,887 \\
\hline $\begin{array}{l}\text { Sivil havacılık işletmesinde yöneticiler, çalışan performansını arttırmanın bir } \\
\text { yolu olarak kalitenin arttırılması gerekliliğine inanır. }\end{array}$ & 0,846 & \\
\hline
\end{tabular}


Sivil havacılık işletmesinde üst yönetim, çalışma ortamını performansı olumlu $\quad 0,869$ etkileyecek hale getirmek için çaba sarf eder.

\begin{tabular}{ll}
\hline Sürekli Gelişme & 0,796
\end{tabular}

Sivil havacılık işletmesi, yenilikçiliği destekler ve yenilikçi yaklaşımlardaki $\quad 0,860$ hataları en aza indirmeye yönelik bir süreç tasarımı uygular.

Sivil havacılık işletmesi, tüm iş süreçlerinde kalitenin ve performans arttırıcı $\quad 0,890$

faktörlerin sürekli iyileştirilmesini vurgular.

Sivil havacılık işletmesi, müşterilerin ihtiyaç ve yetenekleri doğrultusunda $\quad 0,856$ strateji ve planlar geliştirilip uygular.

Sivil havacılık işletmesi, tüm ürün, hizmet ve süreçlerin sürekli olarak $\quad 0,868$ incelenmesi ve geliştirilmesini teşvik eder.

\begin{tabular}{lc}
\hline Takım Çalışması & 0,842
\end{tabular}

Sivil havacılık işletmesinde çalışanlar, bir bütünün parçası olarak hizmet $\quad 0,833$ kalitesini yükseltme konusunda bir sorumluluğu olduğunun bilincindedir. Sivil havacılık işletmesi, çalışanlarının nitelikli görevlere katılımını ve $\quad 0,926$ dolayısıyla bu tür görevlere bağlılıklarını sağlamayı amaçlayan çalışmalar yapar.

Sivil havacılık işletmesi, kalite ve performans sorunlarını çözmek için, takım $\quad 0,920$ çalışması yapar.

Sivil havacılık işletmesinde iş doyumuna yönelik stratejiler, planlı ve sistematik 0,919 bir şekilde takım çalışmalarıyla gerçekleşir.

\begin{tabular}{lc}
\hline $\begin{array}{l}\text { Sürekli Ĕgitim } \\
\text { Sivil havacılık işletmesinde, ihtiyaç duyulan konularda çalışanlara eğitimler } \\
\text { verilir. }\end{array}$ & 0,770 \\
$\begin{array}{l}\text { Sivil havacılık işletmesinde, çalışanların nitelikli bir eğitim alması için gerekli } \\
\text { kaynaklar bulunur. }\end{array}$ & 0,878 \\
$\begin{array}{l}\text { Sivil havacılık işletmesinde çalışanlar, birden fazla görev gerçekleştirmek için } \\
\text { eğitim alır. }\end{array}$ & 0,781 \\
$\begin{array}{l}\text { Sivil havacılık işletmesinde yaşanılan tecrübeler, eğitim aracı olarak } \\
\text { değerlendirilir. }\end{array}$ & 0,861 \\
\hline
\end{tabular}

Tablo 3: Örgüt İkliminin Geçerlilik ve Güvenirlik Analizi

\begin{tabular}{lcc}
\hline & KMO & $\begin{array}{c}\text { Cronbach's } \\
\text { Alpha }\end{array}$ \\
\hline Çalışma Ortamı & $\mathbf{0 , 8 2 3}$ & \\
Sivil havacılık işletmesinde çalışanlar, yöneticileriyle ve birbirleriyle sürekli ve 0,877 & \\
açık bir iletişim halindedir. & 0,848 & 0,903 \\
Sivil havacılık işletmesindeki çalışanlar, iş arkadaşları ile ortak çalışmalar & & \\
yapar ve birbirlerinin fikirlerine değer verir. & 0,910 & \\
Sivil havacılık işletmesinde çalışanlar, işlerini yaparken farklı yöntemleri & & \\
seçme konusunda özgürdür. & 0,886 & \\
Sivil havacılık işletmesinde, çalışanların yetenek ve becerilerini & & \\
kullanabilecekleri bir ortam mevcuttur. & $\mathbf{0 , 7 5 8}$ & 0,876 \\
\hline Güven Duygusu & 0,906 & 0,885 \\
Sivil havacılık işletmesi, çalışanlarına iş güvencesini sağlar. & 0,738 \\
Sivil havacılık işletmesi, çalışanlarına adil davranmaktadır. & 0,916 \\
Sivil havacılık işletmesi çalışanları güvenilirdir. & $\mathbf{0 , 8 4 8}$ \\
Sivil havacılık işletmesi çalışanları, görüşlerini rahatlıkla dile getirir. & \\
Doyum & & \\
\hline
\end{tabular}

Sivil havacılık işletmesinde çalışanlar, yaptıkları işi sever ve ekibin değerli bir 0,833 üyesi olduğunu hisseder. 
Sivil havacılık işletmesinde çalışanlar, istedikleri önemli şeyleri elde etme $\quad 0,796$ olanağına sahiptir.

Sivil havacılık işletmesinde çalışanlar, yaptıkları işten ötürü toplumda saygın $\quad 0,873 \quad 0,886$ bir kişi olma şansını elde eder.

Sivil havacılık işletmesi, çalışanlarına kişisel gelişim imkânı sağlar.

0,801

Sivil havacılık işletmesinde çalışanlar, yaptıkları işten gurur duyar.

0,853

Tablo 4: İş Tatmini Geçerlilik ve Güvenirlik Analizi

\begin{tabular}{|c|c|c|}
\hline & KMO & Cronbach's Alpha \\
\hline $\begin{array}{l}\text { Sivil havacılık işletmesinde, çalışanların performansına bağlı olarak } \\
\text { ücretlendirme yapılır. }\end{array}$ & 0,755 & \\
\hline $\begin{array}{l}\text { Sivil havacılık işletmesi çalışanları, aldığı ücret ne kadar yüksek olursa } \\
\text { yaptıkları işten o kadar zevk alır. }\end{array}$ & 0,460 & \\
\hline $\begin{array}{l}\text { Sivil havacılık işletmesinde aynı işi yapan çalışanlara adaletli ücretlendirme } \\
\text { yapılır. }\end{array}$ & 0,713 & \\
\hline $\begin{array}{l}\text { Sivil havacılık işletmesinde, çalışanın terfi etmesini sağlayan bir terfi } \\
\text { sistemi vardır. }\end{array}$ & 0,775 & \\
\hline $\begin{array}{l}\text { Sivil havacılık işletmesi, çalışanlarının yetenek ve performansına dayalı bir } \\
\text { terfi sistemi uygular. }\end{array}$ & 0,814 & \\
\hline Sivil havacılık işletmesi, çalışanların kariyer gelişimini teşvik eder. & 0,864 & 0.918 \\
\hline $\begin{array}{l}\text { Sivil havacılık işletmesinde iyi çalışanların üst düzey bir konuma } \\
\text { yükselmesi mümkündür. }\end{array}$ & 0,813 & \\
\hline $\begin{array}{l}\text { Sivil havacıllk işletmesi, işin gerçekleştirebilmesi için ihtiyaç duyulan araç } \\
\text { gereci temin eder. }\end{array}$ & 0,687 & \\
\hline $\begin{array}{l}\text { Sivil havacılık işletmesi, çalışma ortamının fiziksel faktörlerinin } \\
\text { uygunluğunu sağlar. }\end{array}$ & 0,733 & \\
\hline $\begin{array}{l}\text { Sivil havacılık işletmesi, çalışanların sağlığına ve güvenliğine uygun } \\
\text { çalışma ortamı sağlar. }\end{array}$ & 0,745 & \\
\hline $\begin{array}{l}\text { Sivil havacılık işletmesi, çalışma ortamının temizliğine önem verir ve } \\
\text { uygunluğunu sağlar. }\end{array}$ & 0,804 & \\
\hline
\end{tabular}

Faktör yüklerinin 0,80 ve yukarı olduğu önermelerin mükemmel seviyede, faktör yüklerinin 0,70 ile 0,80 arasında yer aldı $\breve{g} 1$ önermelerin ise iyi seviyede olduğu görülmektedir.

\section{Korelasyon Analizleri}

Değişkenler arasındaki ilişkinin derecesini ve yönünü belirlemek amaciyla korelasyon analizi yapılmıştır. Hipotez modelimizde bağımsız değişkenimiz toplam kalite yönetimi ve örgüt iklimi iken; bağımlı değişkenimiz iş tatmini olmaktadır. 
Tablo 5: Toplam Kalite Yönetimi ve Örgüt İklimi Alt Faktörleri İle İş Tatmini Korelasyon Analizi

\begin{tabular}{|c|c|c|c|c|c|c|c|c|c|c|}
\hline Boyutlar & 1 & 2 & 3 & 4 & 5 & 6 & 7 & 8 & 9 & 10 \\
\hline 1 & 1 & & & & & & & & & \\
\hline 2 & $0,533^{* *}$ & 1 & & & & & & & & \\
\hline 3 & $0,555^{* *}$ & $0,792^{* *}$ & 1 & & & & & & & \\
\hline 4 & $0,675^{* *}$ & $0,717^{* *}$ & $0,775^{* *}$ & 1 & & & & & & \\
\hline 5 & $0,521^{* *}$ & $0,791^{* *}$ & $0,833^{* *}$ & $0,817^{* *}$ & $1^{* *}$ & & & & & \\
\hline 6 & $0,567^{* *}$ & $0,660^{* *}$ & $0,699^{* *}$ & $0,728^{* *}$ & $0,796^{* *}$ & $1^{* *}$ & & & & \\
\hline 7 & $0,277^{* *}$ & $0,651^{* *}$ & $0,651^{* *}$ & $0,507^{* *}$ & $0,665^{* *}$ & $0,522^{* *}$ & $1^{* *}$ & & & \\
\hline 8 & $0,252^{* *}$ & $0,628^{* *}$ & $0,624^{* *}$ & $0,512^{* *}$ & $0,655^{* *}$ & $0,507^{* *}$ & $0,835^{* *}$ & $1^{* *}$ & & \\
\hline 9 & $0,466^{* *}$ & $0,603^{* *}$ & $0,671^{* *}$ & $0,658^{* *}$ & $0,637^{* *}$ & $0,636^{* *}$ & $0,663^{* *}$ & $0,702^{* *}$ & $1^{* *}$ & \\
\hline 10 & $0,306^{* *}$ & $0,612^{* *}$ & $0,671^{* *}$ & $0,553^{* *}$ & $0,660^{* *}$ & $0,603^{* *}$ & $0,741^{* *}$ & $0,774^{* *}$ & $0,733^{* *}$ & $1^{* *}$ \\
\hline
\end{tabular}

**. Kolerasyon 0.01 seviyesinde anlamlı (Çift Taraflı).

1: Müşteri odaklılık, 2: Tam katılım, 3: Liderlik, 4: Sürekli gelişme, 5: Takım çalışma, 6: Sürekli Eğitim, 7: Çalışma ortamı, 8: Güven duygusu, 9: Doyum, 10: İş tatmini.

Tablo 5'de toplam kalite yönetimi ve örgüt iklimi alt faktörleri ile iş tatmini ölçeği arasındaki korelasyon analizine ilişkin bilgiler yer almaktadır. Sivil havacılık işletmesinde toplam kalite yönetimi ve örgüt iklimi alt faktörleri (müşteri odaklılık, tam katılım, liderlik, sürekli gelişme, takım çalışma, sürekli eğitim, çalışma ortamı, güven duygusu, doyum) ile iş tatmini arasında güçlü bir ilişki olduğu belirlenmiştir.

\section{Regresyon Analizleri}

Anket çalışmasındaki bağımsız değişkenlerin, bağımlı değişken üzerindeki önemlerini belirlemek amacıyla, çoklu regresyon analizleri yapılmıştır.

Tablo 6: Toplam Kalite Yönetimi ve Örgüt İklimi Alt Faktörleri İle İş Tatmini Arasındaki Regresyon Analizleri

\begin{tabular}{|c|c|c|c|c|c|}
\hline & \multicolumn{2}{|c|}{ Standartlaştırılmamış Katsayılar } & \multirow{2}{*}{$\begin{array}{c}\begin{array}{c}\text { Standartlaştırılmış } \\
\text { Katsayılar }\end{array} \\
\text { Beta }\end{array}$} & \multirow[t]{2}{*}{$\mathrm{t}$} & \multirow[t]{2}{*}{ Anlamlılık } \\
\hline & $\mathrm{B}$ & Std. Error & & & \\
\hline (Sabit) & 0,693 & 0,196 & & 3,530 & 0,001 \\
\hline Müşteri odaklılık & $-0,093$ & 0,058 & $-0,094$ & $-1,603$ & 0,111 \\
\hline Tam katılım & $-0,014$ & 0,067 & $-0,016$ & $-0,215$ & 0,830 \\
\hline Liderlik & 0,164 & 0,076 & 0,182 & 2,147 & 0,033 \\
\hline Sürekli gelişme & $-0,042$ & 0,084 & 0,183 & $-0,503$ & 0,616 \\
\hline Takım çalışma & $-0,010$ & 0,090 & 0,184 & $-0,109$ & 0,914 \\
\hline Sürekli Eğitim & 0,167 & 0,072 & 0,185 & 2,308 & 0,022 \\
\hline Çalışma ortamı & 0,126 & 0,064 & 0,186 & 1,965 & 0,051 \\
\hline Güven duygusu & 0,264 & 0,066 & 0,187 & 3,981 & 0,000 \\
\hline Doyum & 0,248 & 0,066 & 0,188 & 3,745 & 0,000 \\
\hline
\end{tabular}

Bağımlı Değişken; İş tatminidir.

Tablo 6'daki veriler 1şı̆̆ında, toplam kalite yönetimi ve örgüt iklimi alt değişkenleri iş tatmini puanlarını istatistiksel bakımdan anlamlı bir şekilde açıklamaktadır. Liderlik $(p=0,033)$ ve sürekli eğitimin $(\mathrm{p}=0,022)$ iş tatminini etkilediği sonucuna ulaşılmıştır. Ancak müşteri odaklılık $(p=0,011)$, tam katılım $(p=0,830)$, sürekli gelişme $(p=0,616)$ ve takım çalışması $(p=0,914)$ alt 
değişkenlerinin iş tatminini etkilemediği tespit edilmiştir. Örgüt iklimi alt faktörlerinden güven duygusu $(\mathrm{p}=0,000)$ ve doyumun ( $\mathrm{p}=0,000)$ iş tatmini pozitif yönde etkilediği görülmektedir.

Toplam kalite yönetimi ve örgüt iklimi alt faktörlerindeki değişimin \% 69'u iş tatmini ile açıklanmaktadır. Toplam kalite yönetimi ve örgüt iklimindeki her 1 birimlik değişim, iş tatmininde $\%$ 71'lik bir değişim meydana getirmektedir.

\section{Hipotezlerin Değerlendirilmesi}

Analizler sonrası istatistik tekniği kullanılarak incelenen hipotezlere ilişkin değerlendirme sonuçları Tablo 7'de yer almaktadır.

Tablo 7: Değerlendirme Sonucunda Hipotezler

\begin{tabular}{|c|c|}
\hline Hipotezler & Sonuç \\
\hline $\begin{array}{l}\mathrm{H}_{1} \text { Toplam kalite yönetimi ilkelerinin iş tatmini üzerinde doğrudan ve pozitif yönde } \\
\text { bir etkisi vardır. }\end{array}$ & Desteklendi \\
\hline $\begin{array}{l}\mathbf{H}_{1 \mathbf{a}} \text { Toplam kalite yönetimi ilkelerinden müşteri odaklılık ilkesi, iş tatmini üzerinde pozitif } \\
\text { bir etkiye sahiptir. }\end{array}$ & Desteklenmedi \\
\hline $\begin{array}{l}\mathbf{H}_{\mathbf{1 b}} \text { Toplam kalite yönetiminin tam katılım ilkesi, iş tatmini üzerinde doğrudan ve pozitif } \\
\text { bir etkiye sahiptir. }\end{array}$ & Desteklenmedi \\
\hline $\mathbf{H}_{\mathbf{1 c}}$ Toplam kalite yönetiminin liderlik ilkesi, iş tatmini üzerinde pozitif etkiye sahiptir. & Desteklendi \\
\hline $\begin{array}{l}\mathbf{H}_{\mathbf{1 d}} \text { Toplam kalite yönetiminin sürekli gelişme ilkesi, iş tatmini üzerinde pozitif bir etkiye } \\
\text { sahiptir. }\end{array}$ & Desteklenmedi \\
\hline $\begin{array}{l}\text { He }_{1 \mathbf{e}} \text { Toplam kalite yönetimi ilkelerinden takım çalışması, iş tatmini üzerinde pozitif bir } \\
\text { etkiye sahiptir. }\end{array}$ & Desteklenmedi \\
\hline $\begin{array}{l}\text { Hop Toplam kalite yönetiminin sürekli eğitim ilkesi, iş tatmini üzerinde pozitif bir etkiye } \\
\text { sahiptir. }\end{array}$ & Desteklendi \\
\hline $\mathrm{H}_{2}$ Örgüt iklimi ile iş tatmini arasında doğrudan ve pozitif yönde bir etki vardır. & Desteklendi \\
\hline $\begin{array}{l}\mathbf{H}_{2 \mathrm{a}} \text { Örgüt iklimi bileşenlerinden çalışma ortamı ile iş tatmini arasında pozitif yönlü bir } \\
\text { ilişki vardır. }\end{array}$ & Desteklenmedi \\
\hline $\begin{array}{l}\mathbf{H}_{2 b} \text { Örgüt iklimi bileşenlerinden güven duygusu ile iş tatmini üzerinde pozitif bir ilişki } \\
\text { vardır. }\end{array}$ & Desteklendi \\
\hline $\mathbf{H}_{\mathbf{2 c}}$ Örgüt iklimi bileşenlerinden doyum ile iş tatmini üzerinde pozitif bir ilişki vardır. & Desteklendi \\
\hline
\end{tabular}

\section{Sonuç ve Değerlendirmeler}

Lojistik sektörü içerisinde yer alan, katma değeri yüksek, ülkelerin kalkınmasında kaldıraç görevi üstlenen sivil havac1lık faaliyetleri önem arz etmektedir. Küreselleşmenin etkisiyle artan rekabet ortamında sivil havacılık işletmelerinin en uygun stratejileri hayata geçirmeleri gerekmektedir.

Sivil havacılık alanında faaliyet gösteren işletmelerde toplam kalite yönetiminin ve örgüt ikliminin iş tatmini üzerindeki etkisi araştırıldığı bu çalışmada toplamda 186 katılımcı üzerinden analiz yapılmıştır. Geçerlilik ve güvenirlik analizi sonucunda toplam kalite yönetimi, örgüt iklimi ve iş tatminine yönelik ölçüm modellerinin uyum değerlerinin iyi düzeyde olduğu ve modelin yap1 geçerliliğinin sağlandığı ortaya çıkmıştır. Liderlik ve sürekli eğitim faktörleri ile iş tatmini arasındaki ilişkinin anlamlı olduğu saptanmıştır. Müşteri odaklılık, tam katılım, sürekli gelişme ve takım çalışması faktörleri ile iş tatmini arasındaki ilişkinin anlamlı olmadığı sonucuna ulaşılmıştır. Örgüt İklimi alt faktörlerinden güven duygusu ve doyum ile iş tatmini arasındaki ilişkinin anlamlı olduğu tespit edilmiştir. 
Çalışmamızda elde edilen sonuçlar, literatürü destekler niteliktedir. İnce (2008) çalışmasında turizm sektöründe toplam kalite yönetiminin iş tatmini üzerindeki etkisini analiz etmiştir. İşin niteliği, ücret, çalışma süreleri, yönetsel ortam unsurlarının iş tatmini üzerinde pozitif bir etkisi olduğu sonucuna ulaşılmıştır. Bal ve Berkin (2010) çalışmalarında, enerji sektöründe toplam kalite yönetimi ile örgüt iklimi arasındaki ilişkiyi incelenmiştir. Toplam kalite yönetimi uygulamalarına başlanılmadan önce örgüt ikliminin bilinmesi gerektiğinin altı çizilmektedir. Çekmecelioğlu (2006) çalışmasında, örgüt ikliminin alt faktörlerinin (otonomi ve özgürlük, yönetimin desteği, rol belirsizliği) iş tatmini üzerinde pozitif yönlü bir etkisi olduğu sonucuna ulaşılmıştır. Doğan ve Üngüren (2012) sağlık sektöründe örgüt iklimindeki sıcak arkadaşlık ortamının, iş arkadaşları ve yöneticileri tarafından desteğin olmasının, örgütsel yapıdaki netliğin, teşvik ve ödüllendirme sisteminin etkin olmasının iş tatmini üzerinde olumlu bir etki yarattığını belirlemiştir.

Bu sonuçlar ışığında, sivil havacılık sektöründe işgörenlerin iş tatminini arttırmaya yönelik atılacak adımlarda dikkat edilmesi gereken noktalar;

•Sivil havacılık sektöründe toplam kalite yönetimi anlayışı işgörenlerin işin bütününü anlamasına yardımcı olacaktır.

-Toplam kalite yönetimi yaklaşımı, sivil havacılık alanındaki işgörenlerin yetenek ve becerilerinden en yüksek düzeyde yararlanılmasına, bu değerlerin örgüt içerisinde geliştirilmesine olanak sağlayacaktır.

-Toplam kalite yönetimi ilkeleri sivil havacılık alanında faaliyet gösteren işletmelerin misyon, vizyon ve stratejilerinde yer almalidir.

İşletmelerde kalite bilincinin oluşması örgüt iklimini etkilemekte ve daha rasyonel kararlar alınabilmektedir.

-Sivil havacılık alanındaki çalışanların tatmin düzeylerini ölçen ve örgüt iklimini belirlemeye yönelik çalışmalar yaygınlaştırılmalıdır. Çalışanların istek ve beklentilerini belirlemek için zaman ve kaynak ayrilmalidır.

-Sivil havacılık alanındaki işletmelerde görev alan yöneticilerin, çalışanlarda istek ve beklentilerini dikkate alması, astlarını cesaretlendirmesi ve inisiyatif kullanmalarına imkan vermeleri, ödül ve teşvik sistemin daha etkinleştirmeleri örgüt iklimi açısından fayda sağlayacaktır.

-Sivil havacılık işletmelerinde sıcak bir örgüt ikliminin hakim olması, çalışanlarda mesleki bağl11ıklarının yüksek olmasına ve gönüllü olarak işletmeye katkı sağlamalarına kaynaklık edecektir.

Çalışmanın sadece sivil havacılık alanında faaliyet gösteren bir işletmede yapılması kısıt oluşturmaktadır, o yüzden sonuçlar bütün sivil havacılık sektörü adına genellik teşkil etmemektedir.

Çalışmanın birçok havayolu işletmesinde ve lojistik işletmelerinde uygulanmasının, hem akademik açıdan hem de sektörel açıdan daha faydalı olacağı öngörülmektedir.

\section{Kaynakça}

Anderson, J.C., Rungtusanatham M., Schroeder, R.G., Devaraj, S. (1995). "A Path Analytic Model of a Theory of Quality Management Underlying the Deming Management Method: Preliminary Empirical Fendinse", Decision Sciences, 26(5), 637-658.

Akbulut, Y., Kutlu, G. (2016). “Örgüt İkliminin Belirlenmesi: Kamu Hastanesi Örneği”, Hacettepe Sağllk İdaresi Dergisi, 19(3), 255-270. 
Akdağ, M. (2005). “Toplam Kalite Yönetimi ve Örgüt İçindeki Yeri”, Selçuk Üniversitesi İletişim Fakültesi Akademik Dergisi, 4(1), 159-170.

Akın, H.B., Günay, T.K. (2015). “TGS Yer Hizmetleri A.Ş.'de ISO 10002 Müşteri Mennuniyeti Kalite Yönetimi Sisteminin Uygulanması ve İstatiksel Olarak Değerlendirilmesi”, Anadolu Bil Meslekokulu Dergisi, 37, 33-48.

Akkoç, İ., Çalışkan, A., Turunç, Ö. (2012). “Örgütlerde Gelişim Kültürü ve Algılanan Örgütsel Desteğin İş Tatmini ve İş Performansına Etkisi: Güvenin Aracılık Rolü”, Yönetim ve Ekonomi Dergisi, 19 (1), 105-135.

Al-khalifa, K.N., Aspinwall, E.M. (2000). "The Development of Total Quality Management in Qatar", The TQM Magazine, 12(3), 194-204.

Arslan, E.T., Demir, H. (2017). "İşe Angaje Olma ve İş Tatmini Arasındaki İlişski: Hekim ve Hemşireler Üzerine Nicel Bir Araştırma”, Yönetim ve Ekonomi, 24(2), 371-389.

Aykaç, B., Özer, M.A. (2006). "Toplam Kalite Yönetiminin Kamu Kuruluşlarında Uygulanması: Sorunlar ve Yeni Arayışlar”, Gazi Üniversitesi İktisadi ve İdari Bilimler Fakültesi Dergisi, 8 (3), 171-202.

Azım, M.T., Haque, M.M., Chowdhury, R. A. (2013). "Gender, Marital Status and Job Satisfaction an Empirical Study", International Review of Management and Business Research, 2 (2), 488-498.

Bakır, M., Bal, H.T., Akan, Ş. (2017). "Türk Sivil Havacılık Sektörünün Değerlendirilmesinde Bütünleşik Swot-Ahs Yaklaşımı”, Journal of Aviation, 1(2), 154-169.

Bal, Y., Berkin, E. E. (2010). Toplam Kalite Yönetimi Bağlamında Örgüt İkliminin İncelenmesi ve Bir Enerji Şirketinde Uygulama, Yönetim Dergisi, 21(65), 107-129.

Bou-Llusar, C., Escrig-Tena, A., Roca-Puig, V., Martin, I. (2009). "An Empirical Assessment of the EFQM Excellence Model: Evaluation as a TQM Framework Relative to The MBNQA Model", Journal of Operations Management, 27(1), 1- 22.

Boymul, E., Özeltürkay, E.Y. (2017). "İş Tatmini ve Örgütsel Bağl1lığın Tükenmişlik Sendromu Üzerindeki Etkisi: Bir Sanayii Kuruluşunda Uygulama”, Journal of Yasar University, 12(46), 93-102.

Clark, A. E. (1997). “Job Satisfaction and Gender: Why are Women so Happy at Work? ", Labour Economics, 4(4), 341-372.

Chaulagain, N., Khadka, D. K. (2012). "Factors Influencing Job Satisfaction Among Healthcare Professionals at Tilganga Eye Centre, Kathmandu, Nepal", International Journal of Scientific Technology Research, 1(11), 32-36.

Claver, E., Tar'1, J.J., Molina, J.F. (2003). "Critical Factors andRresults of Quality Management: An Empirical Study," Total Quality Management and Business Excellence, 14(1), 91-118.

Conca, F.J., Llopis, J., Tar'1, J.J. (2004). "Development of a Measure to Assess Quality Management in Certified Firms," European Journal of Operational Research, 156 (3), 683-697. 
Cua, K. O., Mckone, K. E., Schroeder, R. G. (2001). "Relationships Between Implementation of TQM, JIT, and TPM and Manufacturing Performance", Journal of Operations Management, 19(6), 675-694.

Çalıyurt, K. (2012). Havayollarımda Kurumsal Yönetim ve Bağımsız Denetim, Ekin Yayınevi, Bursa.

Çekmecelioğlu, H.G. (2006). "Örgüt İklimi, Duygusal Bağlılık ve Yaratıcılık Arasındaki İlişkilerin Değerlendirilmesi: Bir Araştırma”, Atatürk Üniversitesi İktisadi ve İdari Bilimler Dergisi, 20(2), 295-310.

Das, A., Paul, H., Swierczek F.W. (2008). "Developing and Validating Total Quality Management (TQM) Constructs in the Context of Thailand's Manufacturing Industry", Benchmarking: An International Journal, 15(1), 52-72.

Das, A., Robert, B.H., Roger J. C., Soumen. G., (2000). "A Contingent View of Quality Management: The Impact of International Competition on Quality”, Decision Sciences, 31 (3), 649-689.

Dedeoğlu, B.B., Çelik, S., İnanır, A., Altay, H. (2016). "Etik Liderlik, Örgütsel Bağl1lık ve İş Tatmini Arasındaki İlişkide: Cinsiyet ve Çalışma Süresinin Farklılaştırıcı Rolü”, Yönetim ve Ekonomi Araştırmaları Dergisi, 14 (4), 45-70.

Demircan, N., Ceylan, A. (2003). “Örgütsel Güven Kavramı: Nedenleri ve Sonuçları”, Celal Bayar Üniversitesi İktisadi ve İdari Bilimler Dergisi, 10(2), 139-150.

Doğan, H., Üngüren, E. (2012). "Örgüt İklimi ve İş Tatmini İlişkisi: Hemşirelere Yönelik Karşılaştırmalı Bir Analiz Çalışması”, International Journal of Economic and Administrative Studies, 4 (8), 27-46.

Eroğluer, K., Yılmaz, Ö. (2015). "Etik Liderlik Davranışlarının Algılanan Örgüt İklimi Üzerine Etkisine Yönelik Bir Uygulama: İş Yaşamında Yalnızlık Duygusunun Aracılık Etkisi”, İşletme Araştırmaları Dergisi, 7 (1), 208-308.

Erturgut, R. (2009). “Toplam Kalite Yönelimli Eğitim Kurumlarında Eğitim Yöneticilerinin Dönüştürücü ve Sürdürümcü Liderlik Düzeylerinin Karşışştırılması: M.E.B. Merkez ve Taşra Teşkilatındaki Örgütlerde Ampirik Bir Araştırma”, Elektronik Sosyal Bilimler Dergisi, 8 (30), 181-199.

Federici, R. A., Skaalvik, E. M. (2012). "Principal Selfefficacy: Relations with Jurnout, job Satisfaction and Motivation to Quit", Social Psychology of Education, 15(3), 295-320.

Fuentes-F.M., Albacete-saez, C.A., Lolerns-montes J. (2004). "The Impact of Environmental Characteristics on TQM Principles and Organizational Performance", Omega, 32(6), 425442.

Fuentes-F.M., Llorens-Montes F.J., Albacete-Saez A.C. (2007). "Quality Management Implementation Across ' Different Scenarios of Competitive Atructure: an Empirical Investigation", International Journal of Production Research, 45(13), 2975-2995.

Gök, S. (2009). "Örgüt İkliminin Çalışanların Motivasyonuna Etkisi Üzerine Bir Araştırma”, Uluslararası İnsan Bilimleri Dergisi, 6 (2), 587-605. 
Güzeler, K.A., Dedeoğlu, A.Ö. (2016). “Üniversitelerde İnovasyon Ekosisteminin Geliştirilmesinde Örgüt İklimi, Örgüt Öültürü ve Örgüt Yapısının İnovatif Davranış Üzerindeki Etkisi: Ege Üniversitesi Örneği, Ege Stratejik Araşttrmalar Dergisi, 7, 115-134.

Halis, M., Uğurlu, Ö.Y. (2008). “Güncel Çalışmalar Işı̆̆ında Örgüt iklimi, İş, Güç”, Endüstri İlişkiler ve İnsan Kaynakları Dergisi, 10 (2), 101-123.

Hine, J. (2000). "Integration, Integration, Integration... Planning for Sustainable and Integrated Transport Systems in the New Millennium", Transport Policy, 7, 175-177.

Hwang, I.S ve Kuo, J.H. (2006). "Effect of Job Satisfaction and Percevied Alternative Employement Opportunities on Turnover Intention- An Examination of Public Sector Organizations", Journal of American Academy of Business, 8 (2), 254-259.

İnce, C. (2008). “Toplam Kalite Yönetimi ve Otel İşletmelerinde İşgören Tatminine Etkileri”, Anatolia: Turizm Araştırmaları Dergisi, 19(1), 57-70.

İşcan, Ö.F., Karabey, C.N. (2007). "Örgüt İklimi ile Yeniliğe Destek Algısı Arasındaki İlişki”, Gaziantep Üniversitesi Sosyal Bilimler Dergisi, 6(2), 180-193.

Kasırga, İ., Özbek, O. (2008). "Beden Eğitimi ve Spor Yüksekokullarında Örgüt İklimi”, SPORMETRE Beden Eğitimi ve Spor Bilimleri Dergisi, 6(2), 59-68.

Kiracı, K., Bayrak, U. (2014). "Sivil Havacılık Lisans Mezunlarının İstihdam ve Kariyer Durumları Üzerine Bir Araştırma”, E-International Journal of Educational Research, 5(2), 67-88.

Korkmaz, M. (2011). "İlköğretim Okullarında Örgütsel İklim ve Örgüt Sağlığının Örgütsel Bağl1lık Üzerindeki Etkisi”, Kuram ve Uygulamada Eğitim Yönetimi, 17(1), 117-139.

Kumar, R., Ahmed, J., Shaikh, B. T., Hafeez, R., Hafeez, A. (2013). “Job Satisfaction Among Public Health Professionals Working in Public Sector: A Cross Sectional Study from Pakistan", Human Resources for Health, 11(2), 1-5.

Liao, H., Chuang, A. (2004). "A Multilevel Investigation of Factors Influencing Employee Service Performance and Customer Outcomes", Academy of Management Journal, 47(1), 41-58.

Litwin, G, H., Stringer, R,A. (1974), Motivation and Organizational Climate, 3rd Edition, Harvard University Press, Boston.

Mehra, S., Ranganathan, S., (2008). "Implementing Total Quality Management with a Focus on Enhancing Customer Satisfaction", International Journal of Quality \& Reliability Management, 25(9), 913-927.

Mrayyan, M.T. (2005). "Nurse Job Satisfaction and Retention: Comparing Public to Private Hospitals in Jordan", Journal of Nursing Management, 13, 40-50.

Oğuzhan, T., Beğenirbaş, M., Topcu, M. K. (2017). "İş Tatmininin Belirleyicileri Olarak Psikolojik Sermaye ve Duygusal Emek: Banka Çalışanları Üzerine Bir Araştırma”, Business \& Management Studies: An International Journal, 5(2), 330-344.

Orhan, U., Komşu, U.C. (2016). "Akademisyenlerde Özyeterlik Algılarının ve Tükenmişlik Düzeylerinin, Öğrenmeye Yönelik Tutuma ve İş Tatminine Etkisi”, Anadolu Üniversitesi Sosyal Bilimler Dergisi, 16(3), 1-18.

Ölçer, F. (2005). "Departmanlı Mağazalarda Motivasyon Üzerine Bir Araştırma", Erciyes Üniversitesi Iktisadi ve İdari Bilimler Fakültesi Dergisi, 25, 1-26. 
Öktem, Ş., Kızıltan, B., Öztoprak, M. (2016). “Örgütsel Güven ile Örgüt İkliminin Örgütsel Özdeşleşme, İş tatmini ve İşten Ayrılma Niyeti Üzerine Etkileri: Otel İşletmelerinde Bir Uygulama", Isşletme Araştırmaları Dergisi, 8 (4), 162-186.

Örücü, E., Yumuşak, S., Bozkır, Y. (2006). "Kalite Yönetimi Çerçevesinde Bankalarda Çalışan Personelin İş Tatmini ve İş Tatminini Etkileyen Faktörlerin İncelenmesine Yönelik Bir Araştırma”, Yönetim Ve Ekonomi Dergisi, 13 (1), 44-45.

Özbağ, G.K. (2012). "Örgüt İkliminin Yeniliğe Destek Algısı Üzerindeki Etkilerini Belirlemeye Yönelik Bir Araştırma”, Dokuz Eylül Üniversitesi İktisadi ve İdari Bilimler Fakültesi Dergisi, 27(2), 145-161.

Özçakar, N. (2010). "Bir Kamu Kuruluşundaki Toplam Kalite Yönetimi Uygulamalarının Değerlendirilmesi”, Journal of the School of Business Administration, 39(1), 106-124.

Öztürk, A., Özdemir, F. (2003). İşletmelerde Personel Güçlendirmeye Dayalı İş Doyumunun Artırılmas1, Íktisadi ve İdari Bilimler Dergisi, 17(1-2), 189-202.

Prajogo, I. D., Sohal, S.A. (2006). "The Integration of TQM and Technology/R\&D Management in Determining Quality and Innovation Performance," Omega, 34(3), 296-312.

Reed, R., Lemark, D.J., Mero, N.P. (2000). "Total Quality Management and Sustainable Competitive Advantage", Journal of Quality Management, 5, 5-26.

Roche, K. (2014). "Job Satisfaction and the Educated Entrepreneur", Journal of Small Business \& Entrepreneurship, 27(4), 353-368.

Samson, D., Terziovski, M. (1999). "Relationship Between Total Quality Management Practices and Operational Performance", Journal of Operations Management, 17(4), 393-409.

Schneider, B., Reichers, A.E., (1983). “On The Etiology Of Climates”, Personnel Psychology, 36(1), 19-39.

Schwepker, C.H. (2001). "Ethical Climate's Relationship to Job Satisfaction, Organizational Commitment and Turnover Intention in the Salesforce", Journal of Business Research, 54, $39-52$.

Sezgin, F., Kılınç, A.Ç. (2011). "İlköğretim Okulu Öğretmenlerinin Örgüt İklimine İlişkin Algılarının İncelenmesi”, Gazi Eğitim Fakültesi Dergisi, 31(3) ,743-757.

Shalley C., Gilson L. and Blum T. (2000). "Matching Creativity Requirements and the Work Environment: Effects on Satisfaction and Intentions to Leave", Academy of Management Journal, 43 (2), 215-223.

Sila, I. (2007). "Examining the Effects of Contextual Factors on TQM and Performance Through the Lens of Organizational Theories: An Empirical Study," Journal of Operations Management, 25(1), 83-109.

Silva M., Luisa L. and Conceiçao B. (2004). "OSCI: An Organizational and Safety Climate Inventory”, Safety Science, 42(3), 205-220.

Sökmen, A., Aydıntan, B. (2016). "Kariyer Geleceği Algısının İş Tatmini ve İşten Ayrılma Niyetine Etkisi: Bir Kamu Kurumunda Araştırma”, İşletme Araşstırmaları Dergisi, 8(3) , 251-263.

Suki, N. M. ve Suki, N. M. (2011). "Job Satisfaction and Organizational Commitment: The Effect of Gender", International Journal of Psychology Research, 6 (5), 1-15. 
Şeker, B. D., Zırhlıŏlu, G. (2009). "Van Emniyet Müdürlüğü Kadrosunda Çalışan Polislerin Tükenmişlik, İş doyumu ve Yaşam Doyumları Arasındaki İlişkilerin Değerlendirilmesi”, Polis Bilimleri Dergisi, 11(4), 144-151.

Şentürk, C., Sağnak, M. (2012). “illköğretim Okulu Müdürlerinin Liderlik Davranışları ile Okul İklimi Arasındaki İlişki”, Türk Eğitim Bilimleri Dergisi, 10(1), $29-47$.

Şimşek, S., Kara, H. (2017). "İş Tatmini - İş Devri Niyeti İlişkisine Yönelik Bir Araştırma: Özel Güvenlik Sektörü Örneği”, Gümüşhane Üniversitesi Sosyal Bilimler Enstitüsü Elektronik Dergisi, 8(1), 85-101.

Talebi, N., Yıldırım, A.E. (2017). "Türkiye'de Sivil Havacılık Sektöründe Müşteri İlişkileri Yönetimi: Turkish Ground Services A.Ş. örneği”, Anadolu Bil Meslek Yüksekokulu Dergisi, 46, 85-96.

Tar1, J.J. (2005). “Components of Successful Total Quality Management”, The TQM Magazine, 17 (2), 182-194.

Tari, J.J., Molina, Jose, F., Castejon, J.L. (2007). “The Relationship Between Quality Management Practices and Their Effects on Quality outcomes", European Journal of Operational Research, 183, 483-501.

Tavas, B., Tekiner, M.A. (2016). "İş Tatmini Düzeylerinin Çalışanların Demografik Yapıları ile İlişkisi Üzerine Bir Araştırma: Türk Polis Teşkilatı Örneği”, International Journal Of Eurasia Social Sciences, 7 (22), 195-207.

Tepe Küçükoğlu, M. (2018). "Psikolojik Güçlendirme, İş Tatmini ve Çalş̧an Performansı Arasındaki İlişkiler: Türkiye'deki Üniversiteler Genelinde Bir Araştırma”, Verimlilik Dergisi, 3, 143-164.

Tutar, H., Altınöz, M. (2010). “Örgütsel İklimin İşgören Performansı Üzerine Etkisi: Ostim İmalat İşletmeleri Çalışanları Üzerine Bir Araştırma”, Ankara Üniversitesi Sosyal Bilimler Fakültesi Dergisi, 65 (2), 195-218.

Türen, U., Gökmen, Y., Tokmak, İ., Bekmezci, M. (2014). “Güvenlik İklimi Ölçeği’nin Geçerlilik ve Güvenilirlik Çalışması”, Süleyman Demirel Üniversitesi İktisadi ve İdari Bilimler Fakültesi Dergisi, 19 (4), 171-190.

Türk, A. (2018). "Kişisel Durum Değişkenlerinin Çalışan Performansı ile İlişkisi: Sivil Havacılık Sektöründe Bir Uygulama”, Nişantaşı Üniversitesi Sosyal Bilimler Dergisi, 6(2), 1-20.

Ugboro, I. O., Obeng, K. (2000). "Top Management Leadership, Employee, Empowerment, Job Satisfaction and Customer Satisfaction in TQM Organisations: An Emprical Study", Journal of Quality Management, 5 (2), 247-272.

Ustasüleyman, T. (2011). “Toplam Kalite Yönetimi Uygulamalarının Firma Performansı Üzerine Etkisi: Türkiye'nin 500 Büyük Firmasına Yönelik Bir Araştırma”, Gazi Üniversitesi İktisadi ve İdari Bilimler Fakültesi Dergisi, 13(2), 67-96.

Uysal, H.T., Aydemir, S. (2014). "Örgütsel İklimin Çalışma Psikolojisine Etkisi: Sağlık Sektöründe Bir Araştırma”, Turkish Studies, 9 (2), 1557-1574.

Uysal, H.T. (2013). "Stajyer Çalışanların Mesleki Bağl1lık Gelişimine Örgüt İkliminin Etkisi", Business and Economics Research Journal, 4 (3), 93-110. 
Varol, F., Karaer, M., Ortakarpuz, M. (2017). “İlaç Mümessillerinin Örgütsel Bağlılığının, İş Tatmininin ve İșten Ayrılma Niyetinin Demografik Faktörler Bağlamında İncelenmesi”, Turkish Studies, 12 (31), 279-302.

Yılmaz, M.K. (2017). "Yolcu Hizmetlerinde Çalışan Memnuniyeti: Havacılık İşletmelerinde Vardiyalı Çalışanlar Üzerine Bir Araştırma", İnsan ve Toplum Bilimleri Araştırmaları Dergisi,6(6), 127-137.

Yüksel, H. (2014). "Sivil Havacılığın Gelişimi ve Küreselleşme Sürecine Katkıları: Türkiye Örneği”, Süleyman Demirel Üniversitesi Vizyoner Dergisi, 5(11), 1-20.

Zu, X., Fredendall, L., Douglas, T. (2008). "The Evolving Theory of Quality Management: The Role of Six Sigma," Journal of Operations Management, 26 (5), 630-650. 